Meta

Journal des traducteurs

Translators' Journal

\title{
The Self-Taught Translator
}

From Rank Amateur to Respected Professional

\section{Claude Schmit}

Volume 11, numéro 4, décembre 1966

La formation du traducteur

URI : https://id.erudit.org/iderudit/004045ar

DOI : https://doi.org/10.7202/004045ar

Aller au sommaire du numéro

Éditeur(s)

Les Presses de l'Université de Montréal

ISSN

0026-0452 (imprimé)

1492-1421 (numérique)

Découvrir la revue

Citer cet article

Schmit, C. (1966). The Self-Taught Translator: From Rank Amateur to Respected Professional. Meta, 11(4), 123-126. https://doi.org/10.7202/004045ar d'utilisation que vous pouvez consulter en ligne.

https://apropos.erudit.org/fr/usagers/politique-dutilisation/ 


\section{THE}

SELF-TAUGHT

TRANSLATOR

FROM

RANK AMATEUR

TO

RESPECTED PROFESSIONAL

On the day the workers stared at each other in confusion on the Tower of Babel, the translator was born. Despite this long-ago creation, translating has yet to evolve into an organized profession. Most translators are the product of a combined accident that finds them bi- or multilingual and untrained in those courses which are required for such occupations as law, engineering, medicine - or plumbing. In brief, they are self-taught. By the nature of its membership, the translating profession is thus akin to public relations, advertising, creative writing or politics where innate ability plus experience are the major qualifications.

\section{THORNS AMONG THE ROSES}

The self-taught translator's world suffers from one basic flaw: he who pays the piper - the client - is generally unilingual and therefore not competent to call the proper tune. As a result, the work of the self-taught translator is allowed to range in quality from the often pitiful to the sometimes highly professional. Unfortunate as it is, this uneven performance has little chance of improving markedly as long as the profession fails to persuade the public that translating is a skilled art and that asking some young thing to «put that into French 》- or another language - « and mail it to $\mathrm{Mr} . \mathrm{X} \gg$ is an insult to the recipient and to his native tongue. Until that happens, mediocrity will survive in the profession, inaccuracies spiced with barbarisms will pass for translations, and the competent practitioner will continue to be tarred with the brush used on his less deserving colleagues.

\section{BASIC REQUIREMENTS}

What, then, will help a self-taught translator become a competent, respected and financially successful member of the profession? The list of requirements probably should include - particularly in Quebec where pressure is being applied at several levels to set norms for the French language - most of the following:

- some academic training in, at least, one's native language

- an inborn sixth sense or feel for languages 
- equal mastery of both languages

- constant practice and/or study

- specialization in a limited number of topics

- a sense of humour and a professional outlook

\section{ACADEMIC TRAINING}

The necessity for academic training - whether at an early age or through adult education courses - is as easily overlooked by those who lack it as it is apparent in those who possess it. The person who has learnt one or several languages solely through practice is generally inclined to believe that fluency alone guarantees excellence in translating. Unaware of grammatical and syntactical pitfalls, he or she will blithely step where angels fear to tread and produce translations which, although quite understandable, nevertheless condone and spread the use of barbarisms, solecisms, anglicisms and the whole gamut of deplorable current isms.

Fortunately, the lack of initial academic training can be remedied at relatively little cost, if not without effort. Academic translation courses, stressing language purity, are offered at least in Quebec City, Montreal and Toronto. For a person already fluent in a given language, acquiring grammatical polish should not be too formidable an undertaking.

\section{THE SIXTH SENSE, AN ASIDE \\ TO THE BEGINNER}

Although generalities are dangerous things, it can be advanced on the basis of experience that persons of Slavic origin usually show an aptitude for languages while the efforts of Anglo-Saxons might better be directed towards some other occupation, such as trade and commerce. As a person may be born with perfect pitch, or a gift for mathematics, so others may possess an innate aptitude for languages. Whether they turn to creative writing or to translating often depends on circumstances.

Translating is not a mechanical exercise but requires literary creativity (which is why it may be futile to raise a head of steam over the subject of translation by computers). It partakes of the liberal arts in that every translation is a brainchild. Artistry in translating, as opposed to the job of translating, is not a gift bestowed evenly upon all and there are as few Hemingways in translating as there are in creative writing. As a rule, the good translator is he - or she - who enjoys writing. For lack of creativity, translating becomes a plodding chore conducive to frustration and its attendant ulcers.

Advice to aspiring translators: if you dislike translating after a decent period of trying, drop it before it is too late since translating is one among those specialized careers from which a switch to something else later on is unlikely. But if you like translating, the breadth of subjects it encompasses is such that you will forever have, among other things, the joy of ever-renewed achievement. 


\section{MASTERY OF BOTH LANGUAGES}

So much has been written about the necessity of being as thoroughly fluent in the original language as in the language of rendition that an example will suffice to illustrate the point. "Ce contrat n'est valide que si une commande a été passée 》 was the recent massacre committed upon the standard clause «Subject to prior sale $\gg$ found in some contracts. By this, the seller means that he will honor orders received, on a first-come first-served basis, as long as his stock lasts. Barring an existing recognized French equivalent, the clause could be suitably rendered into: «L'exécution de cette commande dépendra de la disponibilité des stocks ».

The easiest way to court fluency in a language is to speak it. Instead of retiring at every opportunity to some linguistic ghetto (people of the same language lunch together and inhabit the same districts) the translator will make it a profitable point to mix with «the others ». Younger translators may find this suggestion even more palatable if amended to read «with others of the opposite sex and language $\gg$.

\section{PRACTICE AND STUDY}

In nearly every field of human endeavour, including translation, being out of training is a safe prerequisite for failure. Professional translating demands a finely honed talent which, if idle, blunts rapidly. Where a translator is employed at his craft on a part-time basis, every hiatus between translations means a loss of proficiency, every translation requires a major - often unsuccessful - effort of re-adaptation.

Conversely, constant practice not only preserves but develops the translator's professional skills by matching them against novel linguistic challenges.

Practice, in which each difficulty is dealt with as it occurs, is not yet all. It should be complemented by a methodical search for knowledge in the vast field of translation where word combinations, meanings and possibilities of expression know no limit. Analytical, critical reading of the better authors will yield a rich linguistic harvest for storage in anticipation of future assignments.

\section{SPECIALIZATION}

«Qui trop embrasse, mal étreint. » Specialization in nearly every profession is here to stay, whether we like it or not. The sum of human knowledge has increased to such extent that the mind can retain only a fraction of any discipline. So, the vastness of a language, which serves to express every aspect of man's knowledge, from poetry to nuclear physics, cannot be encompassed by one person. This is even truer when applied to two or more languages.

Thus the translator must select a field in which he will become a master, and so broad is the range of subjects that he will stand on excellent chance to become the one and only recognized (and paid) authority in his specialty.

A factor peculiar to the Province of Quebec reinforces the need to become a competent specialist. To be honest with ourselves, we should confess that standards of translation here were not of the highest order some years ago. One 
could get by with something that presumably approximated the meaning of the original. Now, concerted efforts are at work to upgrade French language norms throughout the province to match the standards of other French-speaking areas of the world ${ }^{1}$. No longer is a French translation acceptable on the main grounds of being understandable. Accurate faithfulness to the original, grammatical correctness and syntactical orthodoxy are becoming compulsory standards for every translator. Since one cannot be fully competent in all fields, specialization is one way to reach the required new levels of excellence and a means to survive and prosper.

\section{HUMOUR TO THE RESCUE}

Show me a translator who does not run in a rat race and I'll show you a person who does not translate. A client may have taken weeks or months to write the original copy which, upon completion, he passes on to the printer for immediate production. This is when, seemingly as an afterthought, he hands over a copy of the original to the translator, stating in some $97.3 \%$ of the cases that the translation is to be published simultaneously with the original.

Impossible? No, the miracle occurs every day. Commercial catalogues, annual reports, news releases, technical publications are published in Canada's two languages regularly under such stress. The harrassed translator may feel that he is getting the short end of the stick but I can assure him that there are many other trades whose practitioners labour under an equal or more severe strain.

Nevertheless, the stress is there; the ensuing tension may exacerbate professional pride to the extent that criticism is resented with the strength of despair. Yet, if we take professional writing as a parallel, it is the true professional who accepts corrections with equanimity while the amateur feels that each word edited is a personal affront. Thus, the professional translator should wear an armour of humour and gentle forbearance. Perhaps, criticism of his work is well-founded, hence helpful. Taking clients' or colleagues' remarks with a healthy grain of salt is a powerful antidote for undue stress. As in any other form of endeavour, humour helps one to maintain a balance on the task - and to enjoy serenely, once the task is done, the too few pleasures which are still legally available in this life.

Claude Schmit Montréal

1. French is currently spoken by approximately 155 million people, less than 4 per cent of whom reside in Quebec. 